\title{
MONITORING OF EGYPTIAN COASTAL LAKES USING REMOTE SENSING TECHNIQUES
}

\author{
Noha S. Donia ${ }^{1}$, Hanan Farag ${ }^{2}$ \\ ${ }^{1}$ Environmental hydraulics, Institute of environmental studies and researches, Ain Shams University, Egypt \\ Noha.samir@iesr.asu.edu.eg \\ ${ }^{2}$ Environment and Climate Changes Research Institute (ECRI),National Water Research Center (NWRC), \\ Cairo, Egypt, hanan_farag@yahoo.com
}

KEY WORDS: Change Detection, classification, Land Cover, land reclamation

\begin{abstract}
:
The Northern Lakes play a significant role in Egyptian economy for fish production in Egypt. Until 1991, these Lakes have always contributed more than $40 \%$ of the country's total fish production, but at present this has decreased to less than $12.22 \%$ as they serve as reservoirs for drainage waters, which contaminated with anthropogenic materials. Since Remote sensing and GIS are suitable and valuable techniques to identify the rate of land reclamation of the coastal lakes over the last three decades. This was undertaken using different kinds of imagery to employ historical remotely sensed data to reveal the long-term changes in the physical characteristics of the lagoon. This paper explains how remote sensing coupled with GIS can be used for lake monitoring applied on some Egyptian coastal lakes as example.
\end{abstract}

\section{INTRODUCTION}

\subsection{General Instructions}

Remotely sensed images can be used as a tool to map ecosystems and to detect, monitor and evaluate changes within them thereby supporting the development of resource management strategies. Satellite and airborne systems offer major opportunities for monitoring large scale, earth surface characteristics and provide a database for change detection studies. Remotely sensed data can be used to span temporal and spatial scales ranging from local to aggregated global systems (Graetz,1990). Monitoring global, regional and local areas can be per-formed by restricting the analysis to a single sensor series or by using different satellite data. With the availability of data from remote sensing satellites such as the Landsat series, it has become cost effective and convenient to acquire multi-date images over a greater array of spatial and temporal scales than was possible with aerial photography. The temporal resolution of data (the ability to obtain repeated coverage of a specific geographic area, 16 days in the case of Landsat TM) from such sources permits regular image acquisition over the same area enabling change detection at relatively high tem-poral frequency,(Lillesand et .al, 1998).

Common types of detectable land cover change, which can be monitored using remotely sensed data, include vegetation disturbance and regeneration, agricultural intensification, urban expansion, spatial changes in aquatic ecosystems and hence surface water extent, as well as a variety of soil disturbance processes including overgrazing and soil erosion (Milne,1988) and (Hall et.al, 1991). Satellite and/or airborne data has been demonstrated to have particular use for monitoring water and vegetation changes within aquatic ecosystems including wetlands,(Howman,1988). Remote sensing techniques can enable ecologists and resource managers to monitor the vegetation condition and detect environmental change trends in regions where difficult terrain, poor access, and extreme climate conditions make regular field investigations difficult.

Land use and land cover is dynamic in nature and is an important factor for the comprehension of the interaction and relationship of anthropogenic activities with the environment. Knowledge of the nature of land use and land cover change
(LUCC) and their configuration across spatial and temporal scales is consequently indispensable for sustainable environmental management and development, (Turner et.al, 1994). LUCC has become one of the major issues for environment change monitoring and natural resource management. Identifying, delineating and mapping of the types of land use and land cover are important activities in support of sustainable natural resource management. To understand how LUCC affects and interacts with environmental systems, information is needed regarding what changes occur, where and when they occur, the rates at which they occur, and the social and physical forces that drive those changes, (Lambin et.al, 1994).

Various techniques have been successfully used in the land use/land cover classification and change detection, e.g., pixel based classification, (Foody,1996) and (Duda et.al, 2001), object oriented classification (Geneletti, 2003), [11], artificial neural network classification (Elmqvist et. Al, 2008) and (Kanellopoulos, 1992). -classification comparison change detection (Liu and Wang (2004) and D Mausel et.al (2004), and visual interpretation (Serra and Saurr, 2003) and (Liu, 2004). Post-classification comparison is a common method used for change detection. This method involves independently produced spectral classification results from each end of time interval of interest, followed by a pixel by pixel to detect changes in cover type. A complete matrix is obtained and change classes can be defined by the proper coding of the classification results. The major advantage of this method is the capability of providing a matrix of change in-formation and reducing external impact from atmospheric and environmental differences between the multi-temporal images.

In northern coast of Egypt, remote sensing has made major contributions to monitoring a variety of wetland systems. El(El-Hattab, 2016) used post classification approach to detect and assess land-cover changes of one of the critical coastal zones in Egypt, Abu Qir Bay region, based on the comparative analysis of independently produced classification images of the same area at different dates. In addition to satellite images, socioeconomic data were used with the aid of land use model EGSLR to indicate the relation between Land-cover and landuse changes. Results showed that changes in different land covers reflected the changes in occupation status in particular 
zones, change rates increased dramatically in the period from 2004 to 2013 as remarkable adverse changes were found mainly in fruits and palm trees due to industrialization in the coastal area. Also, a rapid urban-ization monitored along the coastline of Abu Qir Bay zone due to the political conditions in Egypt (25th of January Revolution) within this period.

(Embabi, 2014) used a semi-automated approach based on a broad range of digital image processing for mapping the major geomor-phological landforms of the Bardawil Lake on a medium scale of 1:250,000. The approach is based primarily on data fusion of Land-sat ETM+ image and validated by other ancillary spatial data (e.g. topographic maps, Google images, and GPS in situ data). Interpreta-tions of high-resolution space images by Google's Earth and the large-scale topographic maps $(1: 25,000)$, in particular, revealed new microforms and some detailed geomorphologic aspects of the aid of GPS measurements. It concluded from geological data and geomorphologic aspects that Bardawil Lake is of a tectonic origin.

(Hickmat and Negm, 2016). applied system Maximum likelihood supervised classification was applied to subsets of the Landsat Thematic Mapper (TM), En-hanced The sematic Mapper Plus (ETM+) and Operational Land Imager and Thermal Infrared Sensor (OLI/TIRS) images acquired on 1984, 1998, and 2015, respectively to monitor changes in Manzala Lake. The overall accuracy for the classification of the captured images in 1984, 1998 and 2015 are 83.67\%, 86.33\%, and $89.33 \%$ re-spectively.

(Kafrawy et. Al, 2017) used a combination of LandSat-1(MSS), LandSat-5 (TM), LandSat-7 (ETM+), SPOT-1, SPOT-4, SPOT5, Rapid Eye, and Sentinel-2 Satellite data to analyze temporal changes in Mariut Lake ecosystem. The analysis's identified the rate of environmental changes over the four decades for lake; this was undertaken using satellite images to employ historical remotely sensed data to reveal the long-term changes in the physical characteristics of the Lake.

Finally this paper aim is to demonstrate the utility of remotely sensed imagery for identifying key environmental features within coastal Lakes taking Brullus lake as example.

\section{STUDY AREA}

Northern Lakes from left to right are: Mariout Lake, a salt water lake, between Alexandria and Al_Bouhaira Governorates; Edko Lake, salt water Lake, and it located in Al_Bouhaira Governorate; Burullus Lake, salt water, Western corner of Kafr el-Sheikh Goveronorate; Manzala Lake in the Mediterranean delta coast of Egypt near Port Said, Damietta, Dakahlyia and Sharqyia governorates, it is larg-est brackish water ecosystem and the most productive lake of north-ern coastal lakes $(\sim 1071$ km2), (Abdel-Satar et.al, 2010); Malaha Lake located in PortSaid Governorate; Bardawil Lake is salt water Lake in North Sinai Governorate, as it is fed only by seawater, the lake is composed of two main basins, and several other internal small basins interconnected to one another, (Dewidar, 2004).

Burullus Lake is chosen as case study. The Burullus region lies on the eastern side of the Rosetta branch of the Nile River, occupying a central position along the Mediterranean Nile delta coast of Egypt. It extends between longitudes 300 30' and 310 $10^{\prime} \mathrm{E}$ and latitudes $31021^{\prime}$ and $30035^{\prime} \mathrm{N}$ (figure 1). The total area of Burullus region is about $2068 \mathrm{~km} 2$, includes the water body of the lake. Burullus Lake is considered the second largest lake of the Nile delta, which is about $53 \mathrm{~km}$ long, $13 \mathrm{~km}$ wide and has water depths ranging from 0.5 to $2.5 \mathrm{~m}$, (RAMSAR, 2015)

Burullus Lake as shown in figure (1) is connected to the sea at its north-eastern edge through the Burullus inlet, which is about $250 \mathrm{~m}$ wide and $5 \mathrm{~m}$ deep. The northern border is separated from the Medi-terranean Sea by a strip of land covered with sand bars and dunes. Seven drains and fresh water canals are connected to its eastern, southern and western shores. The lake barriers are sandy and range from 0.4 to $5.5 \mathrm{~km}$ in width. They are generally $<1.5 \mathrm{~m}$ above mean sea level, with beach face slopes ranging between 50 and 130. Low relief backshore and fore dunes characterize the western barrier. The eastern barrier is narrow and backed by coastal barchans dunes. These dunes encroach landward onto a cultivated coastal flat.

Lake Burullus was declared a protectorate by Prime ministerial de-cree 1444 /1998, as in 1998 Lake Burullus was approved as a RAMSAR site in Egypt, the entire area of the lake is formed of nu-merous islets insides it, as well as the sand bar separating the lake from the Mediterranean Sea, with a shoreline of about $65 \mathrm{~km}$. It has an oblong shape extends for a distance of $47 \mathrm{~km}$ along NE-SW axis. Its width in the west does not exceed $5 \mathrm{~km}$, then its increases in the middle to reach an average of $11 \mathrm{~km}$. It is clear that Lake Burullus had lost about $62.5 \%$ of its size during the last two centuries from $1092 \mathrm{~km} 2$ in 1801 to 410 $\mathrm{km} 2$ in 2003. Its depth varies between $40 \mathrm{~cm}$ near the shores and $200 \mathrm{~cm}$ near the sea outlet (boughaz El-Burullus).

Nine drains discharge into Lake Burullus with a total discharge of 3904 million m3/year including agricultural, industrial and domestic wastewater. The Lake serves as reservoir for drainage waters, from agricultural areas through eight drains in addition to the fresh water from Brimbal Canal situated in the western part of the lake. Chemical pollution inside the Lake indicates an industrial growth in the region. The lake's high nutrient environment allows aquatic plants to grow extensively. The subsequent sediment accumulating around roots of the plants effectively sub-divides lake and effects water circulation. In addition, Total suspended solids TSS values are very high, which means high pollution of organic and non-organic material from industrial and agriculture waste. Declining of salinity levels inside the lake is considered as a problem. Total percentage by weight of marine fish species such as Liza Ramada decreased from $16 \%$ in 1973 to less than $1.8 \%$ in 2003 and fresh water fish; Tilapia increased from about $81 \%$ to 98.2 \%.,( Kassas, 2002)

The shallow brackish Lake is mainly affected by uncontrolled creeping of development areas and growing inflow of untreated agriculutural, municipal and industrial drainage water. In addition, there is a lack of permanent continuous and up to date monitoring system capturing the fundamental hydrodynamics and water quality parameters inside the lake system. The main water quality problems in the Lake are the declining salinity level and deteriorating of the water quality of the water inside. Lake Burullus declined from 32 species to 25 ones. All species which have disappeared from the lake are of marine origin. Total fresh water fish increased from $81.7 \%$ to $98.18 \%$ by weight during the period between 1971 and 2003, while the total marine fish decreased from $15.99 \%$ to $1.81 \%$ by weight as the salinity levels are decreasing according to massive increase of agricultural drainage water inflow. In spite of selfpurification capacity and increasing in the number of aquatic plants, the environmental quality of water in Lake Burullus had 
been deteriorating. To conclude, all these circumstances lead to the necessity of establishment of a proper management system to control pollution inside the Lake, (Zingstra, 2013).

Also, from the information and review published there are different records are reported for the shoreline and size of the Lake have al-ways been rather dynamic, all these records are proved that there is declination in Lake Burullus surface area. In 1810 the recorded size of the Lake was $1092 \mathrm{~km} 2$ and gradually the Lake size decreased from 50.270 ha in 1984 to 41.000 ha in 1997 and the circumference from $160.0 \mathrm{~km}$ to $143.0 \mathrm{~km}$ in the same period. Other information indicate a surface of 57,120 ha in 1953 and 42,420 ha in 2000 . The management plan indicates a surface of the Lake of 41,000 hectares and the surface of the open water of 37.000 hectares.

According to analyses of satellite images performed in the frame of the assessment the surface of open water is 32,460 hectares (in 2011), reed beds occupy 16.828 hectares and marsh vegetation 3506 hectares; total: 52,898 hectares . Another study was carried out to map the change of the surface area of the Burullus Lagoon in the Nile Delta using the water indices approach. A set of six satellite images acquired between 1973 and 2011 was employed and the normalized difference water index (NDWI) and the modified normalized difference water index (MNDWI) was applied to quantify the change in the water body area of the lagoon during the study period. Results showed that the lagoon lost $42.8 \%$ of its open water area due to the severe anthropogenic activities, such as the reclaiming of its southern margins for agricultural purposes and the filling caused by the discharge of agricultural wastes ,(Hesham, et.al, 2013).

According to the Management Plan the Lake area decreased during the period 1983 to 1991 with an average rate of 8.600 hectares per year. From 1983 to 1985 the area decreased with 5500 hectares and towards the 1990 the rate decreased further, Wenbo et.al, 2013).

Thus, a good inventory and map of lake system using remote sensing techniques is very useful to understand the spatial distribution of the lake and their linkage with other land units. This will help in planning, management and conservation of lake.

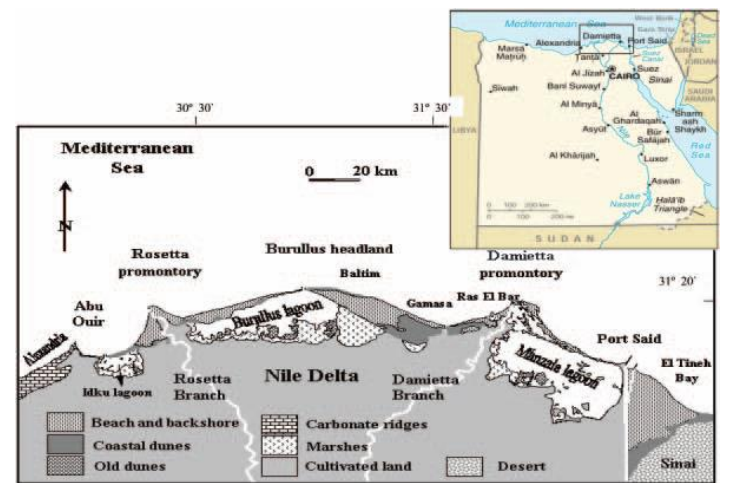

Figure.1 The Burullus Region

\section{METHODOLOGY}

\subsection{Lake delineation using remote Sensing data}

Primarily, in this work Landsat 8 (OLI) 30m data for years 2013 and 2015 have been used. The high and low flow discharged from the drainage system are considered in acquired dates where the high flow is in summer (June, July and August) and the low flow in win-ter (December, January and February). The two acquired images are in February 2015 (winter) and July 2015 (summer). The spring sea-son is also very important in monitoring the changes in vegetation areas in the lake. Therefore, the third acquired image is in May 2013. The multispectral images Landsat 8 operational land imager (OLI) images downloaded from http://glovis.usgs.gov/.Detailed characteristics of the satellite data as wavelengths, spectral bands and spatial resolution are displayed in Table (1).

Table (1) Characteristics of satellite sensors data used in $\mathrm{Bu}-$ rullus Delineation

\begin{tabular}{|c|c|c|}
\hline Image Code & $\begin{array}{l}\text { *Image } \\
\text { Acquisitio } \\
\text { n Date }\end{array}$ & $\begin{array}{l}\text { Wavelength } \\
\text { (micrometers) }\end{array}$ \\
\hline $\begin{array}{l}\text { LC81770382013142LGN0 } \\
1\end{array}$ & $\begin{array}{l}22 \text { May } \\
2013\end{array}$ & $\begin{array}{l}\text { Band 1 - Coastal } \\
\text { aerosol } 0.43 \text { - } \\
0.45 \\
\text { Band 2 - Blue } \\
0.45-0.51\end{array}$ \\
\hline $\begin{array}{l}\text { LC81770382015036LGN0 } \\
0 \\
\text { LC81770382015196LGN0 }\end{array}$ & $\begin{array}{l}05 \\
\text { February } \\
2015\end{array}$ & $\begin{array}{l}\text { Band 3- } \text { Green } \\
0.53-0.59 \\
\text { Band } 4-\text { Red } 0.64 \\
-0.67 \\
\text { Band } 5-\text { Near } \\
\text { Infrared } \quad \text { (NIR) } \\
0.85-0.88\end{array}$ \\
\hline 0 & $\begin{array}{ll}15 & \text { July } \\
2015 & \end{array}$ & $\begin{array}{l}\text { Band } 6 \text { - SWIR } 1 \\
1.57-1.65 \\
\text { Band } 7 \text { - SWIR } 2 \\
2.11-2.29 \\
\text { Band } 8 \\
\text { Panchromatic } 0.50 \\
-0.68 \\
\text { Band } 9 \text { - Cirrus } \\
1.36 \text { - } 1.38 \\
\text { Band } 10 \text { - Thermal } \\
\text { Infrared (TIRS) } 1 \\
\text { 10.60 - 11.19 } \\
\text { Band } 11 \text { - Thermal } \\
\text { Infrared (TIRS) } 2 \\
11.50 \text { - 12.51 }\end{array}$ \\
\hline
\end{tabular}

*Spatial resolution (m): $30 \mathrm{~m}$, No. of spectral bands:12 bits

The ground truth points applied in this work carried out in 9 to 11 May 2013, which is very close to close to the image acquisition month 22 May 2013. The total number of these ground truth points are (42) covering the four main classes (water, vegetation, sand and fish farms) at the lake and its surrounded area. More than $50 \%$ of that collected points were for water class because that mission objective was water quality sampling and measuring the light distribution in the water column for validation and calibration satellite data (eg MERIS). Additional Ground truth data was collected for environ-mental affairs agency (EEAA) 12 points are measured four times per year as and reburial activities. The ground truth points distribution over the lake Burullus wetland area are represented in figure (2). 


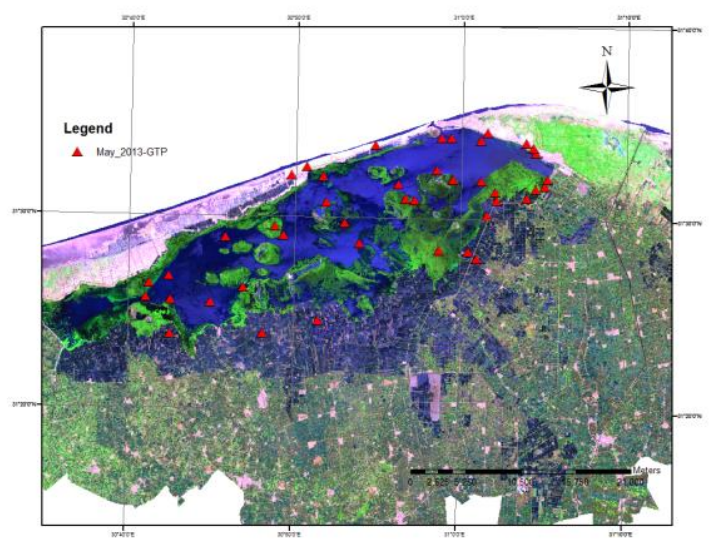

Figure (2) Ground truth points distribution (Image date, May 2013)

\subsection{Developing Lake Water surface}

In Lake Burullus delineation is carried out by applying the super-vised classification (Maximum Likelihood), two band vegetation in-dices as Normal Difference Vegetation Index (NDVI) and Normal Difference Water Index (NDWI). The detailed of lake surface water delineation and classification procedures and water mask extracting are displayed in details in Figure (3).

In this study the specific indices NDVI and NDWI and wavebands, the thresholds for separating water body from other wetland features are defined for the acquired Landsat images. The (NDWIs), calculated from various band combinations, green, near-infrared (NIR) or shortwave-infrared (SWIR), have been successfully applied to Burullus mapping. NDWI is attributed to the optical properties of the surface water in terms of its relationship with the electromagnetic radiation. The near infrared radiation is generally less absorbed by the water body than the middle infrared band at the time where the green band absorption is constant giving this difference in the threshold values.

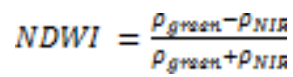

Where, $\rho$ Green and $\rho$ NIR are the reflectance of the green and NIR bands, respectively. NDWI is designed to (1) maximize the reflectance of a water body by using green Wavelengths, (2) minimize the low reflectance in NIR of water bodies, and take advantage of the high reflectance in NIR of vegetation and soil features. As a result, the water body information will be enhanced and the background (vegetation and soil features) information will be restricted in NDWI images, vegetation and soil features,[22].

Theoretically, negative value of NDVI is corresponding to water, so the NDVI developed images is also used in determining the open water surface.

NDVI $=\frac{\rho_{\text {red }}-\rho_{\text {NIR }}}{\rho_{\text {red }}+\rho_{\text {NIR }}}$

The thresholds values for NDWI are varied from 0.05 to 0.15 according to varied water characteristics for each image acquired, where the NDVI values are ranged from -0.12 to -0.26 . The water open surface was estimated for each developed water mask, there is variation was slightly noticed and it could be acceptable re-sults compared with the recent study published in 2013 where the open water surface area was 32,460 hectare.

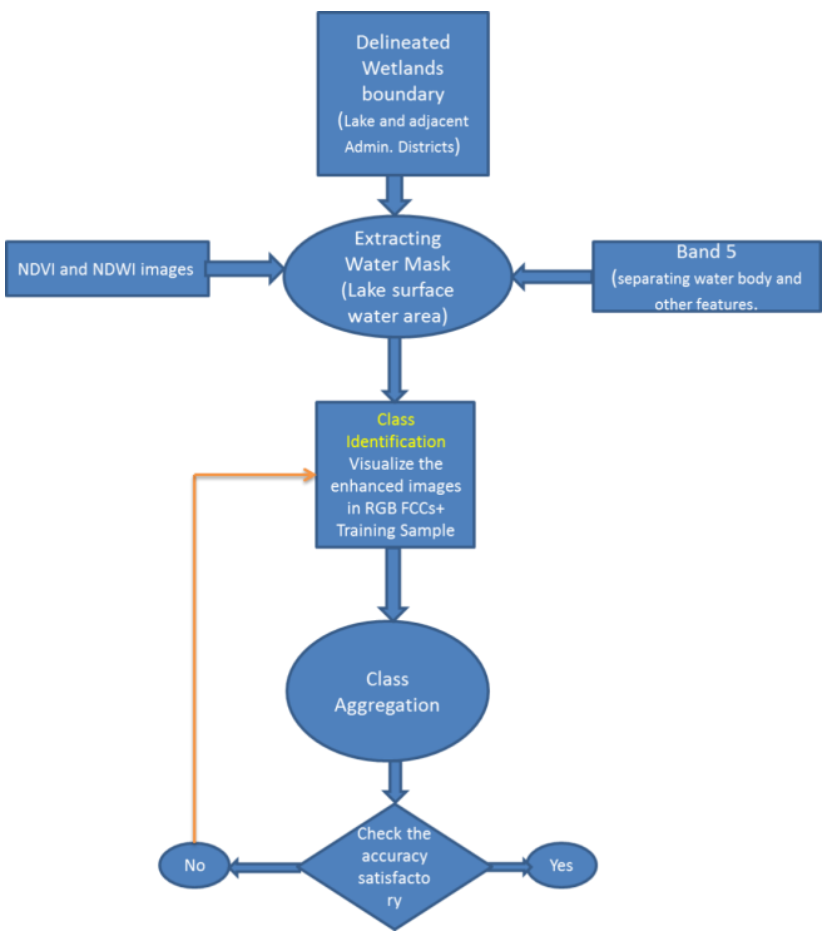

Figure (3) Flow chart of classification process applied

\subsection{Lake Burullus wetland area classification}

The classification of Burullus wetland is carried out by applying un-supervised and supervised classification technique (Maximum likelihood). Five classes are defined, these are Water, Fish ponds, Vegetation, Agriculture and Sand \&urban area. The boundary of the classified area is defined first by the selected five administration boundary surrounded to the Lake. The training sample layer is constructed for each image based on the ancillary data, Google maps and collected information at field work.

The unsupervised and supervised methods (Maximum Likelihood)) are applied in land use wetland area. Five classes are defined, these are: open water surface area, irrigated area (Agriculture class), vegetation, fish aquaculture farms and sand bar \& urban areas.

The accuracies were assessed using the ground truth points plus reference points from Google earth maps. The total number of the points is applied to check the accuracy 292 point. Ground truth 42 point and 250 are reference point. The error matrix is constructed to assess the accuracy for each class and over all accuracy.

\section{RESULTS AND DISCUSSIONS}

Figure (4) and Figure (5) represent NDWI and NDVI images in dates May2013 and July2015 respectively. Figure (6) displays the open water surface area in acquired dates. Figure (7) displays Landsat L8 imaginary July 2015 in false composite color (FCC) where figure (8) shows extracted water mask imposed the classified images July 2015.Figures (9), (10) and 
(11) show the classified images for three dates May2013, Feb 2015 and July2015.

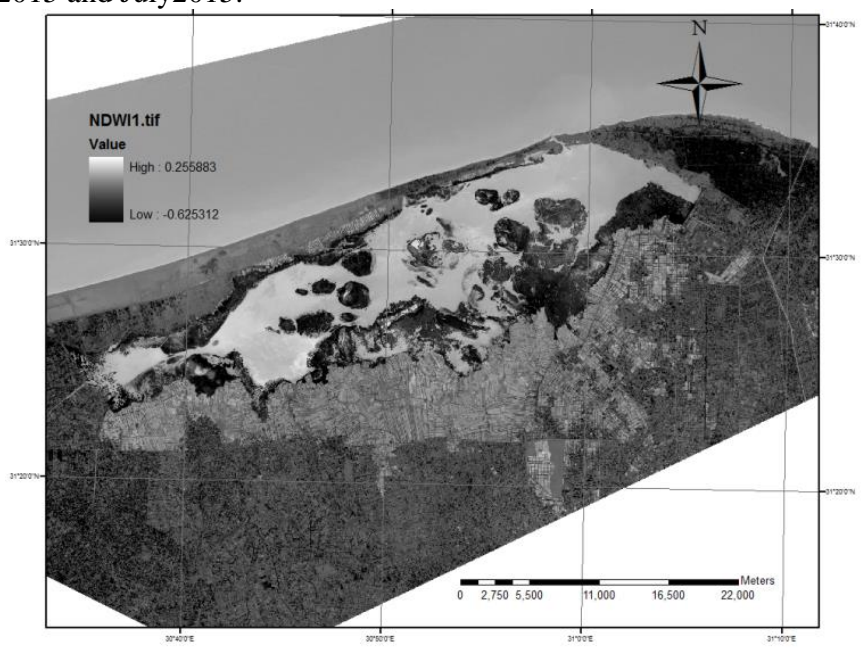

Figure (4) NDWI Map of Lake Burullus (May 2013)

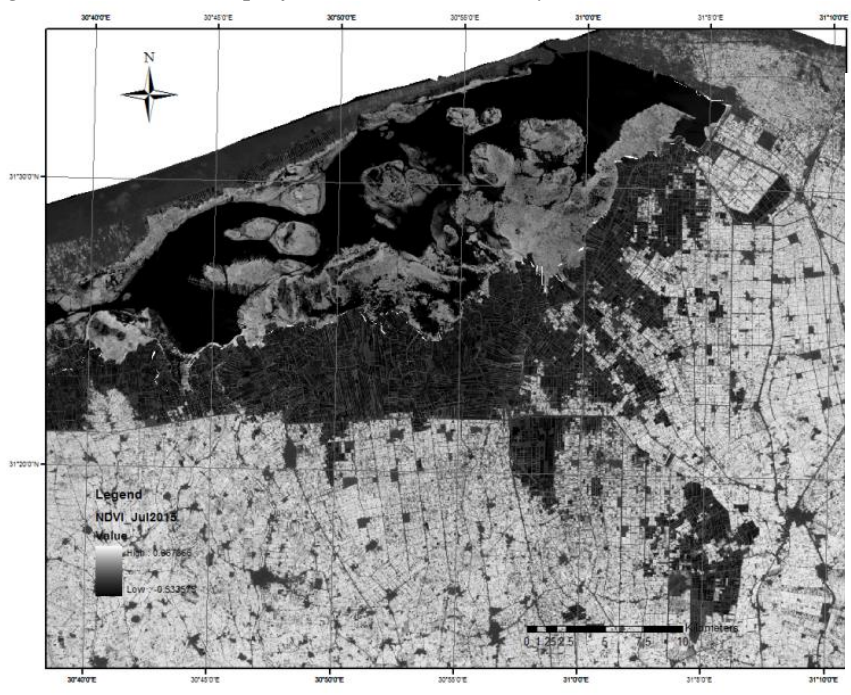

Figure (5) NDVI Map of Lake Burullus (July 2015)
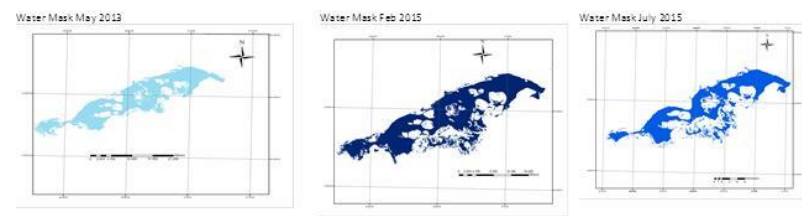

Figure (6) Lake Burullus Water Mask for acquired Imaginary

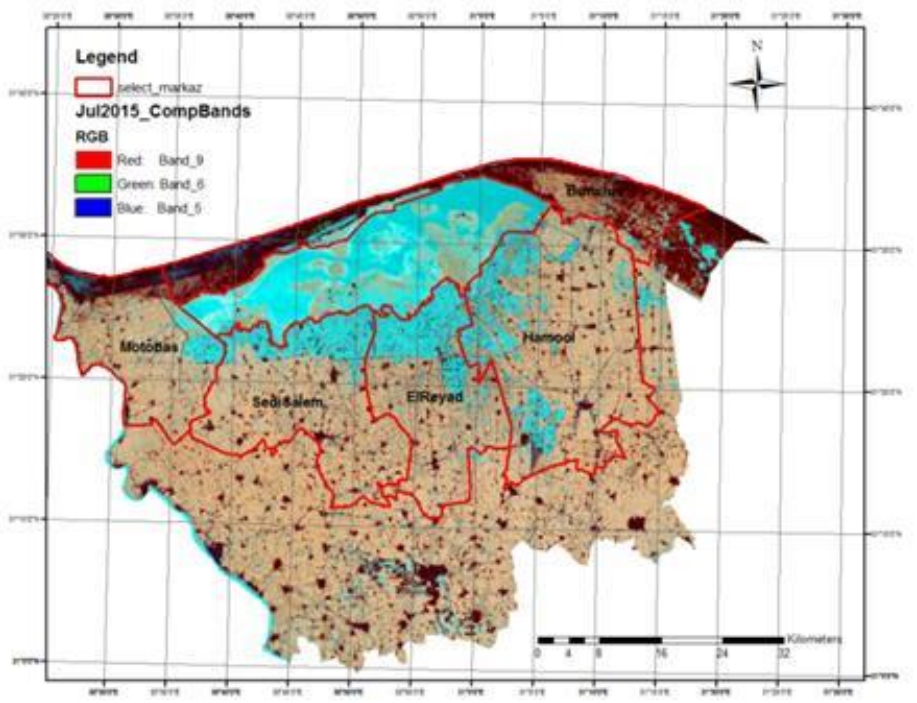

Figure (7) Landsat L8 imaginary July 2015 (FCC RGB)

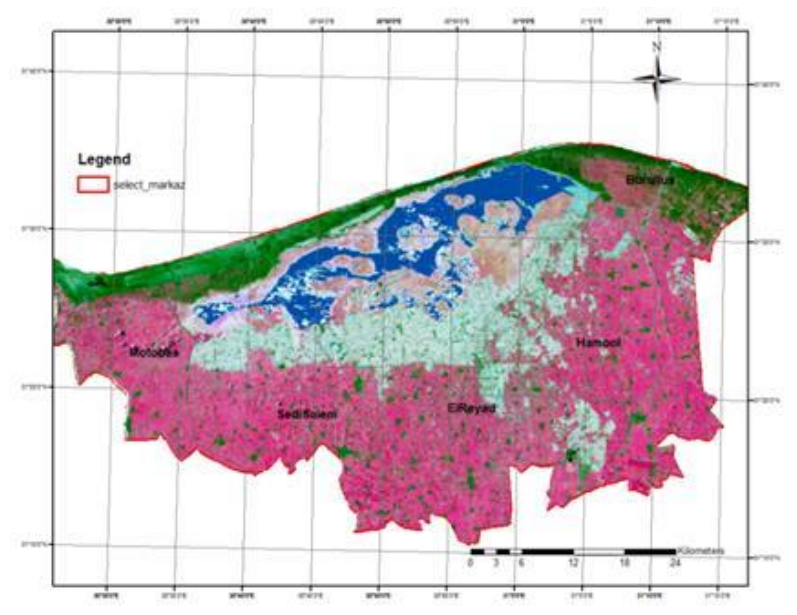

Figure 8) Water Mask July 2015 combined with classified image (FCC RGB)

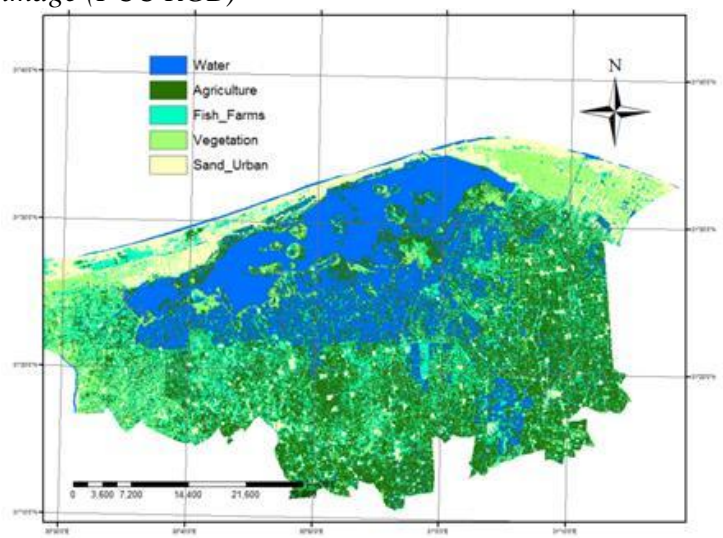

Figure (9) Classification Map May 2013 


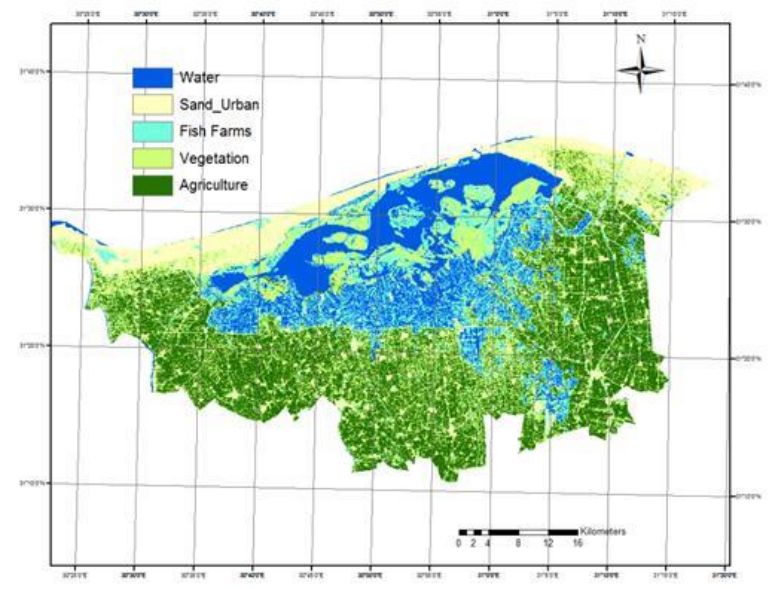

Figure (10) Classification Map Feb 2015

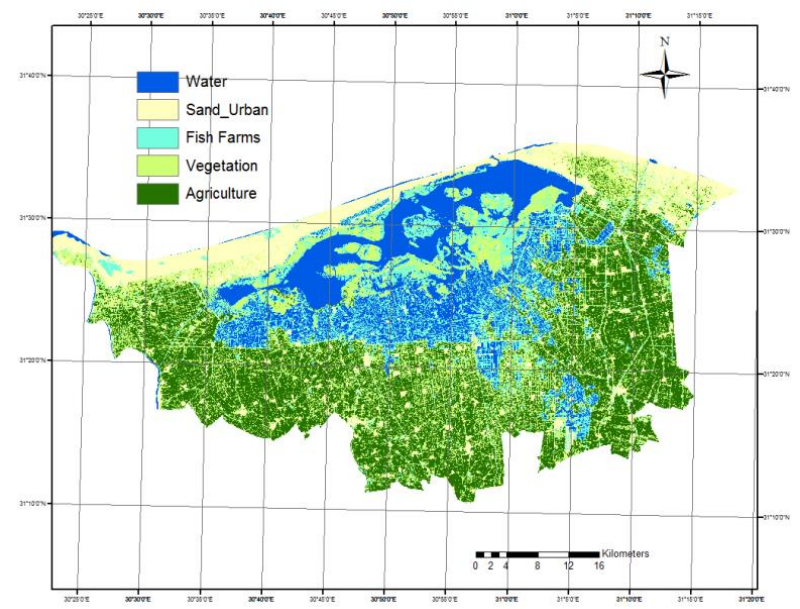

Figure (11) Classification Map July 2015

Table (2) summarizes each identified class area in three different dates plus the reported recent study was interested in classification of Lake Burullus land use.

Table (2) Extracted Areas for each Lake Burullus Wetland Land use classes

\begin{tabular}{|l|l|l|l|l|}
\hline $\begin{array}{l}\text { Class Name/ } \\
\text { Area }\left(\mathrm{Km}^{2}\right)\end{array}$ & \multicolumn{4}{|l|}{ Satellite image } \\
\hline & May 2013 & $\begin{array}{l}\text { February } \\
2015\end{array}$ & July 2017 & \\
\hline Water & 323.3 & 321.7 & 314.4 & \\
\hline $\begin{array}{l}\text { Fish } \\
\text { Aquaculture }\end{array}$ & 418.9 & 430.4 & 436.2 & \\
\hline Agriculture & 1250.3 & 1265.6 & 1308.9 & \\
\hline Vegetation & 229.2 & 234.6 & 229.8 & \\
\hline $\begin{array}{l}\text { Sand \& } \\
\text { Urban areas }\end{array}$ & 257.8 & 249.9 & 247.2 & \\
\hline
\end{tabular}




\section{REFERENCES}

Graetz R, 1990 Remote Sensing of Terrestrial Ecosystem Structure: An Ecologist's Pragmatic View. In: Remote Sensing of Biosphere Functioning, R. Hobbs and H. Mooney, eds. Spring-Verlag, New York, pp 5-30.

Lillesand T J Chipman D Nagel H Reese M Bobo and R Goldman, 1998 Upper Midwest gap analysis program image processing protocol. Rept. for U.S. Geol. Surv. Environ. Manag. Tech. Ctr., Onalaska, WI, EMTC 98-G001, 25 p.

Milne A , 1988 Change Detection Analysis Using Landsat Imagery: A Review of Methodology. Proceedings of IGARSS '88 Symposium, Edinburgh, Scotland, Sept. 23-16,, pp 541-544

Hall F D Botkin D Strebel K Woods and S Goetz, 1991. Largescale Patterns of Forest Suc-cession as Determined by Remote Sensing. Ecology 72(2): 628-640.

Howman A , 1988 The Extrapolation of Spectral Signatures Illustrates' Landsat's Potential to Detect Wetlands. Proceedings of lCARSS '88 Symposium, Edinburgh, Scotland, September 1316. pp 537-539.

Turner B L Meyer W B and Skole D L, 1994. Global landuse/land-cover change: towards an integrated study, Ambio, 23(1), pp. 91-95.

Lambin E F Geist H J and Lepers E , 2003. Dynamics of landuse and land-cover change in tropical regions, Annual Review of Environment and Resources, 28, pp. 205-241.

Foody G M, 1996. Approaches for the production and evaluation of fuzzy land cover classifications from remotely sensed data. International Journal of Remote Sensing, 17(7), pp. 1317-1340.

Duda R O Hart P E and Stork D G, 2001. Pattern Classification. John Wiley \& Sons, NY.

Geneletti D Gorte B G H, 2003 A method for object-oriented land cover classification combining Landsat TM data and aerial photographs, International Journal of Remote Sensing, 24(6), pp. 1273-1286.

Elmqvist B, Ardo J Olsson L, 2008 Land use studies in drylands: an evaluation of object-oriented classification of very high resolution panchromatic imagery, International Journal of Remote Sensing, 29(24), pp. 7129-7140.

Kanellopoulos I Varfis A Wilkinson G G Megier J , 1992. Land-cover discrimination in SPOT HRV imagery using an artificial neural network-a 20-class experiment, International Journal of Remote Sensing, 13 (5), pp. 917-924.

Liu Z Liu A Wang C Niu Z, 2004. Evolving neural network using real coded genetic algorithm (GA) for multispectral image classification, Future Generation Computer Systems, 20(7), pp. 1119-1129.

Lu D Mausel P Brondizio E S And Moran E F, 2004. Change Detection techniques, International Journal of Remote Sensing, 25, pp. 2365-2407.
Serra P Pons X And Saurr D, 2003. Post-classification change detection with data from different sensors: some accuracy considerations, International Journal of Remote Sensing, 24 (16), pp. 3311-3340.

Liu J Tian H Liu M Zhuang D Melillo J Zhang Z, 2005. China's changing landscape during the 1990s: large-scale land transformations estimated with satellite data, Geophysical Research Letters, 32, L02405, p. 5 (doi:10.1029/2004GL021649).

El-Hattab M M , 2016. Applying Post Classification Change Detection Technique to moni-tor an Egyptian Coastal Zone (Abu Qir Bay). The Egyptian Journal of Remote Sensing and Space Science, 19(1), 23-36.

Embabi N S and Moawad M B, 2014 A semi-automated Approach for Mapping Geomorphology of El Bardawil Lake, Northern Sinai, Egypt, using integrated remote sensing and GIS techniques. The Egyptian Journal of Remote Sensing and Space Science, 17(1), 41-60.

Hickmat Hossen and Abdelazim Negm, 2016. Change detection in the water bodies of Burullus Lake, Northern Nile Delta, Egypt, using RS/GIS / Procedia Engineering 154 ( 2016 ) 951 $-958$

Kafrawy S. Donia NS, Mohamed AM, 2017. Monitoring the Environmental Changes of Mariout Lake during the Last Four Decades Using Remote Sensing and GIS Techniques. MOJ Eco Environ Sci 2(5): 00037. DOI: 10.15406/mojes.2017.02.00037

Abdel-Satar A M Goher M E and Sayed M F, 2010. Recent Environmental Changes in Water and Sediment quality of Lake Qarun, Egypt. Journal of Fisheries and Aquatic Science, (2), 56-69.

Dewidar KH M, 2004 Detection of land use/land cover changes for the northern part of the Nile delta (Burullus region), Egypt, International Journal of Marine Geology, 25(20), pp. 40794089.

RAMSAR, 2015, National Report on The Implementation of The Ramsar Convention on Wetlands National Reports to be submitted to the 12 the Meeting of the Conference of the Contracting Parties, Uruguay (2015).

Kassas, M., , 2002. Management Plan for Burullus Protected Area. Med Wet Coast, Global Environment Facility \& Egyptian Environment Affairs Agency, Cairo

Henk Zingstra, 2013. Lake Burullus Local Food Security and Biodiversity under Pressure, Centre for Development Innovation, Wageningen UR.

Hesham M. El-Asmar, Mohamed E. Hereher, Sameh B. El Kafrawy, 2013. Surface area change detection of the Burullus Lagoon, North of the Nile Delta, Egypt, using water indices: A remote sensing approach, The Egyptian Journal of Remote Sensing and Space Sciences (2013) 16, 119-123

Wenbo Li, Zhiqiang Du,, Feng Ling, Dongbo Zhou, Hailei Wang, Yuanmiao Gui, Bingyu Sun and Xiaoming Zhang, 2013. A Comparison of Land Surface Water Mapping Using the Normalized Difference Water Index from TM, ETM+ and ALI, Remote Sens. 2013, 5, 5530-5549; doi:10.3390/rs5115530 